\title{
Epidermis-Activated Gasdermin-A3 Enhances Thermogenesis of Brown Adipose Tissue through IL-6/Stat3 Signaling
}

Qin Chen, ${ }^{\dagger}$ Peiliang Shi, ${ }^{*}$ Dingyu Wang, ${ }^{*}$ Qiyao Liu, ${ }^{*}$ Xu Li, ${ }^{*}$ Yufang Wang, ${ }^{*}$ Dayuan Zou, ${ }^{*}$ Zan Huang, ${ }^{\ddagger}$ Xiang Gao, ${ }^{*}$ and Zhaoyu Lin*

From the State Key Laboratory of Pharmaceutical Biotechnology,* Nanjing Drum Tower Hospital, Model Animal Research Center, Nanjing University, Nanjing; the Department of Oral Surgery, ${ }^{\dagger}$ Ninth People's Hospital, Shanghai Jiao Tong University School of Medicine, Shanghai; and the Jiangsu Province Key Laboratory of Gastrointestinal Nutrition and Animal Health, ${ }^{\ddagger}$ Nanjing Agriculture University, Nanjing, China

\author{
Accepted for publication \\ January $24,2019$. \\ Address correspondence to Xiang \\ Gao, Ph.D., or Zhaoyu Lin, Ph.D. \\ State Key Laboratory of Pharma- \\ ceutical Biotechnology, Nanjing \\ Drum Tower Hospital, Model Ani- \\ mal Research Center, Nanjing \\ University, Pukou District, 12 \\ Xuefu Rd., Nanjing, Jiangsu \\ 210061, China. E-mail: \\ gaoxiang@nju.edu.cn or linzy@ \\ nju.edu.cn.
}

\begin{abstract}
Missense mutations in the gasdermin-A3 (Gsdma3) gene are associated with skin inflammation and hair loss in mice. However, the physiological function of Gsdma3 remains unclear. Herein, we reported that mice carrying the Gsdma3 $\mathrm{Y} 344 \mathrm{H}$ mutation that encodes a presumptive activated form of Gsdma3 show increased heat production along with lower body fat percentages. Detailed analysis indicated that this metabolic phenotype is mediated by serum IL-6-induced up-regulation of thermogenesis in brown adipose tissue. The mutant form of Gsdma3 promotes the expression of IL- 6 in the epidermis in a c-Jun N-terminal kinase (JNK) signaling-dependent manner. The higher whole-body heat production in alopecia and excoriation mice could be suppressed by an IL-6 receptor/GP130 inhibitor. Our results uncovered Gsdma3/IL-6-dependent cross talk between the skin and brown adipose tissue. (Am J Pathol 2019, 189: 1041-1052; https://doi.org/10.1016/ j.ajpath.2019.01.012)
\end{abstract}

Skin is traditionally defined as a barrier for the human body to resist mechanical damage and invasion by pathogenic microorganisms. Recently, several studies found that epidermal lipid metabolism plays a crucial role in maintaining wholebody metabolic homeostasis. ${ }^{1}$ For instance, skin-specific stearoyl-CoA desaturase-1 ( $S c d 1)$ knockout mice showed an increase in energy expenditure and resistance to high-fat diet-induced obesity. ${ }^{2,3}$ Skin also mediates adaptive thermogenesis under cold conditions. Thermoreceptors in the skin can activate the neural circuits that connect with the hypothalamus under cold exposure. The hypothalamus further releases norepinephrine into the blood and activates brown adipose tissue (BAT) heat production. ${ }^{4,5}$

Inflammatory skin diseases, such as psoriasis, are also associated with metabolic syndrome. Psoriasis has been identified as a risk factor for metabolic syndromes, such as obesity and type 2 diabetes, by several clinical studies. ${ }^{6-8}$ Another study reports that after UV irradiation, the epidermis secretes several cytokines to regulate s.c. fat metabolism. ${ }^{9}$ Increase of metabolic rate and heat production is also common after burn injury, along with up-regulation of uncoupling protein 1 (UCP1) in BAT. ${ }^{10-13}$ Even for 9 to 12 months after severe burn, the patients are still in a hypermetabolic situation. ${ }^{14}$ These reports show a close relevance between skin and whole-body metabolism in responding to inflammation. However, the mechanistic relationship between inflammatory skin diseases and metabolic syndrome is still unknown.

The gasdermin-A3 (Gsdma3) gene, a member of the Gasdermin family, is expressed specifically at a high level in the epidermis. ${ }^{15}$ Several mouse strains carrying Gsdma3

Supported by the Ministry of Science and Technology of China grant 2015BAI08B02 (X.G.), the Natural Science Foundation of Jiangsu Province grant BK20181260 (Z.L.), and the National Natural Science Foundation of China grants 31772550 (X.G.), 31301217 (Z.L.), and 31500944 (Z.H.).

Q.C. and P.S. contributed equally to this work.

Disclosures: None declared. 
missense mutations have been reported to associate with cicatricial alopecia, hyperkeratosis, sebaceous gland atrophy, and corneal opacity. ${ }^{16-19}$ Nevertheless, the physiological function of Gsdma3/GSDMA is still unclear. ${ }^{20}$

The alopecia and excoriation (AE) phenotype in Gsdma3 mutant mice (without additional mutations) is mediated by skin inflammation and can be rescued by immunosuppressant. ${ }^{21}$ We also found that the $\mathrm{N}$ terminus of Gsdma3 is the active domain for inducing cell death, and the $\mathrm{C}$ terminus of Gsdma3 suppresses the N-terminus function in a selfinhibitory manner. ${ }^{20}$ Interestingly, all mutations reported so far are missense point mutations in the $\mathrm{C}$ terminus, which abolish its self-inhibition function. Therefore, the mutant forms of Gsdma3 actually represent the active state of Gsdma3. Our finding was confirmed by studies of gasdermin-D (GSDMD), another member of the Gasdermin family. ${ }^{16-19}$ The activated GSDMD is activated by caspase-1/4/ $5 / 11-$ mediated cleavage in the linker region between the $\mathrm{N}$ terminus and the $\mathrm{C}$ terminus. However, the potential protease for Gsdma3 activation remains unknown.

In this study, it was found that Gsdma3 activation in skin showed decreased body fat and increased whole-body heat production. Further study showed that the metabolic change is dependent on the up-regulation of IL-6 expression, which further activates BAT thermogenesis.

\section{Materials and Methods}

Mice

All animal welfare and experimental procedures were approved by the Animal Care and Use Committee of the Model Animal Research Center, Nanjing University (Nanjing, China). The wild-type (WT) C57BL/6J mice were obtained from the National Database of Mouse Genetic Resources (Nanjing, China). The AE strain was generated in an ethyl nitrosourea mutagenesis program, which was reported previously, that had been backcrossed to the C57BL/6J strain for $>10$ generations. ${ }^{21}$ All mice were maintained in a specific pathogen-free animal facility under a 12-hour light-dark cycle at constant temperature $\left(23^{\circ} \mathrm{C}\right)$, fed a standard chow diet ad libitum, and hydrated with acidified water, accredited by the Association for Assessment and Accreditation of Laboratory Animal Care International. The WT littermates were used as controls.

\section{Cell Culture and Treatment}

HaCaT cells were cultured in Dulbecco's modified Eagle's medium (DMEM), supplemented with 10\% fetal bovine serum (FBS; Invitrogen, San Diego, CA), with $5 \% \mathrm{CO}_{2}$ at $37^{\circ} \mathrm{C}$. HaCaT-N and HaCaT-CW cell lines infected by TRIPZ-Gsdma3-N-terminus and TRIPZ-Gsdma3-C-terminus lentivirus were reported previously. ${ }^{20} \mathrm{JNK}$ inhibitor SP600125 and extracellular signal-regulated kinase inhibitor U1026, used to treat HaCaT-N and HaCaT-CW cell lines, respectively, were purchased from Selleck Chem (Houston, TX).

\section{Body Composition Measurement}

Mice body composition parameters, including fat mass and lean mass values, were assessed with dual-energy X-ray absorptiometry using a Lunar PIXImus II densitometer (PIXImus 2; GE Lunar, Chicago, IL), according to the instructions of the manufacturer.

\section{Primary Brown Adipocyte Isolation and Culture}

Primary brown adipocytes were isolated and cultured, as previously described. ${ }^{22}$ Briefly, 2-week-old C57BL/6J mice were sacrificed, and their interscapular brown fat tissues were harvested and digested by collagenase A (CLS004196; Worthington, Lakewood, NJ). Primary brown adipocytes were filtered through $70-\mu \mathrm{m}$ filters and then cultured in DMEM containing $10 \% \mathrm{FBS}$ and $2 \mathrm{nmol} / \mathrm{L} 3,3^{\prime}, 5^{\prime}$-Triiodo-L-thyronine (T3; Sigma-Aldrich, St. Louis, MO). After confluence, primary brown adipocytes were stimulated with DMEM containing 10\% FBS, $850 \mathrm{nmol} / \mathrm{L}$ insulin (Sigma-Aldrich), $0.5 \mu \mathrm{mol} / \mathrm{L}$ dexamethasone (Sigma-Aldrich), $250 \mu \mathrm{mol} / \mathrm{L}$ 3-isobutyl-1-methylxanthine (IBMX; Sigma-Aldrich), $1 \mu \mathrm{mol} / \mathrm{L}$ rosiglitazone (Sigma-Aldrich), $0.125 \mathrm{nmol} / \mathrm{L}$ indomethacin (Sigma-Aldrich), and $2 \mathrm{nmol} / \mathrm{L} \mathrm{T} 3$ for 2 days. The induction medium was switched to DMEM containing 10\% FBS, 160 $\mathrm{nmol} / \mathrm{L}$ insulin, and $2 \mathrm{nmol} / \mathrm{L}$ T3 for 2 days. Then, cells were incubated in DMEM with $10 \%$ FBS and $2 \mathrm{nmol} / \mathrm{L}$ T3. The primary brown adipocytes were treated with serum from $\mathrm{AE}$ or WT mice for 4 hours to harvest.

\section{Administration of Anti-IL-6}

The IL-6-neutralizing monoclonal antibody and the control IgG were produced by Bio X Cell (West Lebanon, $\mathrm{NH}$ ). For specific blocking of IL-6 signaling, mice were intraperitoneally injected with $500 \mu \mathrm{g}$ neutralizing anti-IL-6 monoclonal antibody, which had been shown to be effective in blocking IL-6 signaling in previous work. ${ }^{23}$ In the control group, mice received $500 \mu \mathrm{g} \mathrm{IgG}$ antibody. Antibodies were injected in a volume of $200 \mu \mathrm{L}$ phosphate-buffered saline (PBS) 24 hours before metabolic cage analysis.

\section{Protein Extraction and Western Blot Analysis}

Samples were rinsed quickly in $2 \mathrm{~mL}$ of modified radioimmunoprecipitation assay buffer (radioimmunoprecipitation assay base with $1 \mathrm{mmol} / \mathrm{L} \mathrm{NaF}, 1 \mathrm{mmol} / \mathrm{L} \mathrm{Na}_{3} \mathrm{VO}_{4}, 1 \mathrm{mmol} / \mathrm{L}$ phenylmethylsulfonyl fluoride, and cocktail protease inhibitors; Sigma-Aldrich). The lysate was incubated at $4^{\circ} \mathrm{C}$ for 2 hours while rotating and then centrifuged at $12,000 \times g$ for 15 minutes at $4^{\circ} \mathrm{C}$. The supernatant protein concentrations were determined with Bradford reagent (Sangon Biotech, Shanghai, China). Protein samples were electrophoresed using SDSPAGE with the appropriate percentage of acrylamide (10\% to $15 \%)$, transferred to an Immobio- $\mathrm{P}^{\mathrm{SQ}}$ transfer membrane (Merck Millipore, Tullagreen, Carrigtwohill, Ireland), and 
incubated with primary antibodies. Antibodies used are given in Table 1.

\section{Histology}

Adipose tissues were isolated and fixed in $4 \%$ paraformaldehyde and divided into sections. Hematoxylin and eosin staining was performed routinely. Frozen sections for immunofluorescence were washed in PBS three times, 5 minutes each time, and then blocked in blocking buffer $(5 \%$ bovine serum albumin and $0.1 \%$ Tween-20 in PBS) at room temperature for 1 hour. Then, sections were incubated with primary antibody, which was diluted in blocking buffer overnight at $4^{\circ} \mathrm{C}$. On the following day, sections were washed in PBS and incubated with secondary antibody diluted in PBS at room temperature for 1 hour. Finally, after washing with PBS three times, sections were mounted in $50 \%$ glycerol. Sections were imaged using confocal microscopy (Leica, Buffalo Grove, IL).

\section{RNA Extraction and Quantitative Real-Time PCR}

RNA was extracted using RNAiso reagent (Takara, Dalian, China), according to the manufacturer's instructions. The cDNA was reverse transcribed from $1 \mu \mathrm{g}$ total RNA using a first-strand cDNA synthesis kit (Takara). An ABI 7300 and SYBR Premix Ex Taq (Takara) were used for quantitative real-time PCR. Primer sequences are summarized in Table 2.

\section{Indirect Calorimetry and Metabolic Assays}

Mice were housed individually in a Comprehensive Lab Animal Monitoring System (Columbus Instruments, Columbus, $\mathrm{OH}$ ) with free access to food and water and the same dark and light periods of 12:12-hour cycles. $\mathrm{O}_{2}$ consumption, $\mathrm{CO}_{2}$ production, and activity were measured continuously for 2 days after 1 day to allow for adaptation, and respiratory exchange ratio and heat production were computed automatically. Core body temperatures were detected rectally using a thermocouple (Physitemp, Clifton, NJ).

\section{GTT and Insulin Tolerance Test}

For the glucose tolerance test (GTT) experiment, WT and $\mathrm{AE}$ mice, fasted for 16 hours, were injected intraperitoneally with D (+) glucose (Sigma-Aldrich; $2 \mathrm{~g} / \mathrm{kg}$ body weight). For the insulin tolerance test experiment, WT and AE mice, fasted for 6 hours, were injected intraperitoneally with insulin (Novo Nordisk Pharmaceutical Industries, Malov, Denmark; $0.75 \mathrm{U} / \mathrm{kg}$ body weight). Blood glucose concentrations were measured at $0,15,30,60,90$, and 120 minutes after glucose or insulin administration. Blood glucose concentrations were measured using a Breeze 2 Blood Glucose Meter (Bayer HealthCare LLC, Mishawaka, IN).

\section{Statistical Analysis}

The results were performed by using GraphPad Prism 6 (GraphPad Software, La Jolla, CA) and Excel (Microsoft, Redmond, WA). Data were analyzed with unpaired $t$-test and presented as the means \pm SEM. $P<0.05$ was considered statistically significant.

\section{Results}

\section{Gsdma3-Mutant AE Mice Have Less Body Fat and Higher Heat Production}

There was no significant difference in body weight between $\mathrm{WT}$ and AE male mice $(P=0.1245)$ (Figure 1A). However, the AE mice showed significantly decreased fat mass compared with WT mice when the fat mass and lean mass composition was measured by bone densitometry (dual-energy X-ray absorptiometry or double-energy X-ray absorptiometry; $P=0.0002$ ) (Figure $1 \mathrm{~A})$. The percentage of body fat was also decreased in AE mice $(P<0.0001)$ (Figure 1B). By weighing the dissected BAT $(P=0.0002)$, s.c. fat $(P<0.0001)$, and visceral fat $(P<0.0001)$ tissues, all of the fat tissues were found to be significantly decreased in $\mathrm{AE}$ mice (Figure 1, C and D).

The energy metabolism was compared in WT and AE mice by using metabolic cages. All metabolic cage data

Table 1 List of Primary Antibodies Used in This Study

\begin{tabular}{lll}
\hline Target & Catalog number & Company \\
\hline Phosphorylated Stat3 (Tyr705) & 9145 & Cell Signaling Technology (Danvers, MA) \\
Stat3 & 12640 & Cell Signaling Technology \\
Phosphorylated SAPK/JNK (Thr183/Tyr185) & 4668 & Cell Signaling Technology \\
SAPK/JNK & 9252 & Cell Signaling Technology \\
Phosphorylated Erk1/2 (Y204) & BS4621 & Bioworld (Minneapolis, MN) \\
Erk1/2 & BS1112 & Bioworld \\
Phosphorylated C-Jun (Ser73) & 3270 & Cell Signaling Technology \\
InVivoMAb rat IgG1 isotype control & BE0088 & Bio X Cell \\
InVivoMAb anti-mouse IL-6 & BE0046 & Bio X Cell \\
\hline
\end{tabular}

Erk, extracellular signal-regulated kinase; JNK, c-Jun N-terminal kinase; SAPK, stress-activated protein kinase. 
Table 2 Sequences of qPCR Primers Used in This Study

\begin{tabular}{|c|c|c|}
\hline Primer name & Forward primer & Reverse primer \\
\hline \multicolumn{3}{|l|}{ Human-specific primers } \\
\hline IL-1 $\beta$ & $5^{\prime}$-ATGATGGCTTATTACAGTGGCAA-3' & $5^{\prime}$-GTCGGAGATTCGTAGCTGGA-3' \\
\hline IL-2 & 5'-ААСТCСTGTCTTGCATTGCAC-3' & 5'-GCTCCAGTTGTAGCTGTGTTT-3' \\
\hline IL-4 & $5^{\prime}$-CCAACTGCTTCCСССТCTG-3' & 5'-TCTGTTACGGTCAACTCGGTG-3' \\
\hline IL-6 & $5^{\prime}-$ ACTCACCTCTTCAGAACGAATTG-3' & $5^{\prime}$-CCATCTTTGGAAGGTTCAGGTTG-3' \\
\hline IL-12 & 5'-ACССTGACCATCCAAGTCAAA-3' & 5'-TTGGCCTCGCATCTTAGAAAG-3' \\
\hline TNF- $\alpha$ & 5'-ССТСТСТСТААТСАGСССТСТG-3' & $5^{\prime}$-GAGGACCTGGGAGTAGATGAG-3' \\
\hline IFN- $\alpha$ & $5^{\prime}-\mathrm{ATCTCAGCAAGCCCAGAAGT-3^{ \prime }}$ & $5^{\prime}$-GGGTCTCAGGGAGATCACAG-3' \\
\hline IFN- $\gamma$ & 5'-TCGGTAACTGACTTGAATGTCCA-3' & 5'-TCGCTTCССTGTTTTAGCTGC-3' \\
\hline 36B4 & $5^{\prime}-\mathrm{AGCCCAGAACACTGGTCTC-3^{ \prime }}$ & $5^{\prime}$-ACTCAGGATTTCAATGGTGCC-3' \\
\hline \multicolumn{3}{|l|}{ Mouse-specific primers } \\
\hline $\mathrm{IL}-1 \beta$ & $5^{\prime}$-GCAACTGTTCCTGAACTCAACT-3' & 5'-ATCTTTTGGGGTCCGTCAACT-3' \\
\hline IL-8 & $5^{\prime}$-CAAGGCTGGTCCATGCTCC-3' & 5'-TGCTATCACTTCCTTTCTGTTGC-3' \\
\hline IL-10 & 5'-GCTCTTACTGACTGGCATGAG-3' & 5'-CGCAGCTCTAGGAGCATGTG-3' \\
\hline IL-12 & 5'-TGGTTTGCCATCGTTTTGCTG-3' & 5'-ACAGGTGAGGTTCACTGTTTCT-3' \\
\hline IL-22 & 5'-ATGAGTTTTTCCCTTATGGGGAC-3' & 5'-GCTGGAAGTTGGACACCTCAA-3' \\
\hline IL-17 & 5'-TTTAACTCCCTTGGCGCAAAA-3' & $5^{\prime}$-СТTTCCСТCCGCATTGACAC-3' \\
\hline IL-18 & 5'-GACTCTTGCGTCAACTTCAAGG-3' & 5'-CAGGCTGTCTTTTGTCAACGA-3' \\
\hline IFN- $\alpha$ & 5'-GGCTCTGTGCTTTCCTGATG-3' & $5^{\prime}$-GCGGGAATCCAAAGTCCTTC-3' \\
\hline IFN $-\gamma$ & $5^{\prime}-$ ATGAACGCTACACACTGCATC-3' & 5'-CCATCCTTTTGCCAGTTCCTC-3' \\
\hline TNF- $\alpha$ & 5'-СССТСАСАСТСАGАТСАТСТTСТ-3' & $5^{\prime}$-GCTACGACGTGGGCTACAG- $3^{\prime}$ \\
\hline 36B4 & 5'-GACCGCCTGGTTCTCCTATAA-3' & $5^{\prime}-\mathrm{AGACGATGTCACTCCAACGA-3^{ \prime }}$ \\
\hline Ucp1 & 5'-GGCCTCTACGACTCAGTCCA-3' & $5^{\prime}-$ TAAGCCGGCTGAGATCTTGT-3' \\
\hline Ppara & $5^{\prime}-$ ACTACGGAGTTCACGCATGTG-3' & 5'-TTGTCGTACACCAGCTTCAGC-3' \\
\hline ATP25 & $5^{\prime}-$ GCTGAGGAATGTTCAAGCAGA-3' & $5^{\prime}-$ CCAAGTTCAGGGACATACCC-3' \\
\hline Scd1 & 5'-TGGAAATGCCTTTGAGATGG-3' & $5^{\prime}-$ CCAGCCAGCCTCTTGACTAT-3' \\
\hline Dgat2 & 5'-TCATGGGTGTCTGTGGGTTA-3' & $5^{\prime}-\mathrm{CAGAGTGAAACCAGCCAACA-3^{ \prime }}$ \\
\hline Fasn & $5^{\prime}$-CTCCGTGGACCTTATCACTA-3' & $5^{\prime}$-CTGGGAGAGGTTGTAGTCAG-3' \\
\hline Acacb & $5^{\prime}-$ CGCTCACCAACAGTAAGGTGG-3' & $5^{\prime}$-GCTTGGCAGGGAGTTCCTC-3' \\
\hline Srebf1c & 5'-TGCGGCTGTTGTCTACCATA-3' & $5^{\prime}-$ TGCTGGAGCTGACAGAGAAA-3' \\
\hline Pparr & $5^{\prime}-\mathrm{TCACCGGCAAGTCCAGCCA-3^{ \prime }}$ & $5^{\prime}$-ACACCAGGCCCTTCTCTGCCT-3' \\
\hline Pgc1a & 5'-GGACATGTGCAGCCAAGACTCT-3' & $5^{\prime}-$ CACTTCAATCCACCCAGAAAGCT-3' \\
\hline Tfam & 5'-ATTCCGAAGTGTTTTTCCAGCA-3' & 5'-TCTGAAAGTTTTGCATCTGGGT-3' \\
\hline Prdm16 & 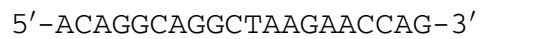 & 5'-CGTGGAGAGGAGTGTCTTCAG-3' \\
\hline$\beta 3$-Adrenergic receptor & 5'-GGCCCTCTCTAGTTCCCAG-3' & $5^{\prime}-$ TAGCCATCAAACCTGTTGAGC-3' \\
\hline
\end{tabular}

Acacb, acetyl-coenzyme A carboxylase beta; Acadl, acyl-coenzyme A dehydrogenase, long-chain; Acadm, acyl-coenzyme A dehydrogenase, medium chain; ATP25, ATPase synthesis protein 25 mitochondrial; Cox4i, cytochrome c oxidase subunit 4I1; Cpt1b, carnitine palmitoyltransferase 1b; Dgat, diacylglycerol 0 acyltransferase 1; Fasn, fatty acid synthase; IFN, interferon; qPCR, real-time quantitative PCR; Ldha, lactate dehydrogenase A; Ldhb, lactate dehydrogenase B; Pgc1a, peroxisome proliferative activated receptor, gamma, coactivator 1 alpha; Ppara, peroxisome proliferator activated receptor alpha; Pparr, peroxisome proliferator activated receptor gamma; Prdm, PR domain containing; Scd1, stearoyl-CoA desaturase-1; Srebf1c, sterol regulatory element binding transcription factor 1; Tfam, transcription factor A, mitochondrial; TNF- $\alpha$, tumor necrosis factor- $\alpha$; Ucp, uncoupling protein. 
A

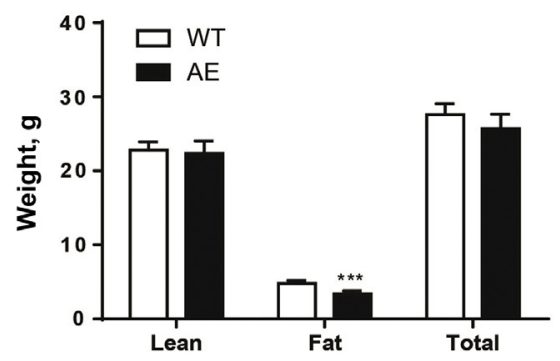

D

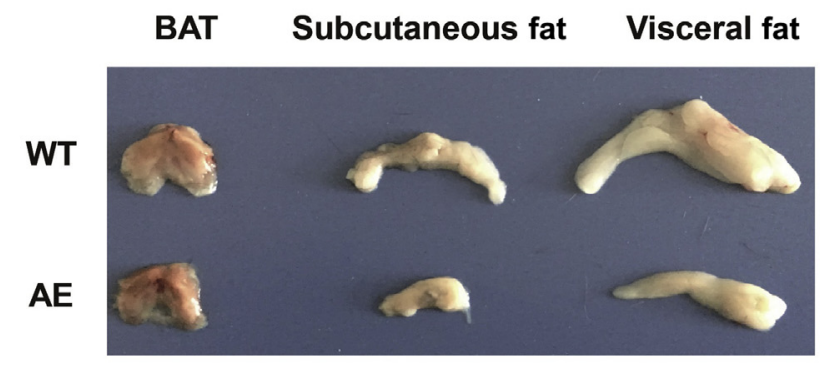

G

H

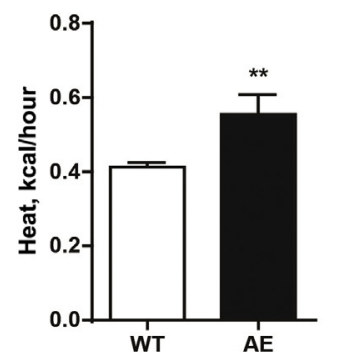

B

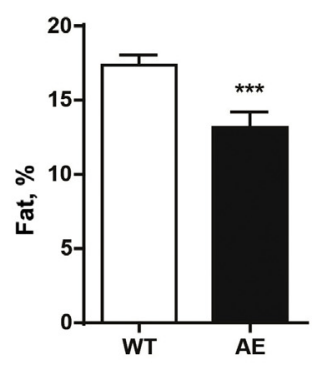

E
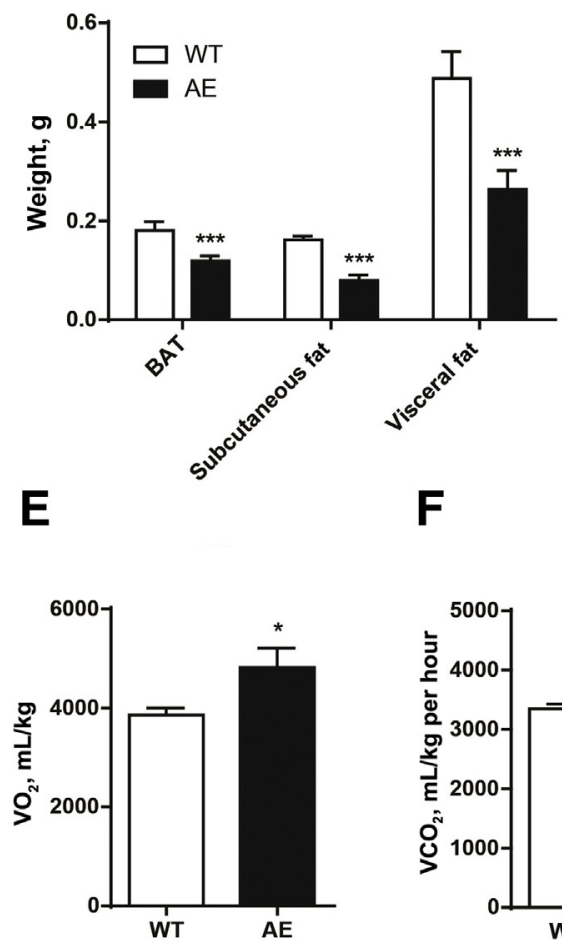

I

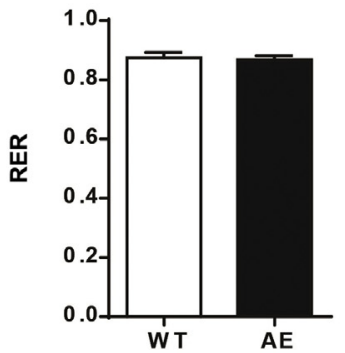

$\mathbf{F}$

Figure 1 Gsdma3-mutant AE mice have decreased percentages of body fat and increased heat production. A and B: Lean mass, fat mass, and total body weight (A) and the fat percentages of WT and AE male mice (B). C: Weight of brown adipose tissue (BAT), s.c. fat, and visceral fat in 3-month-old male WT and AE mice. D: Morphology of BAT, s.c. fat, and visceral fat in 3-month-old male WT and AE mice. E-J: volume of $\mathrm{O}_{2}$ consumption (VO2; E), volume of $\mathrm{CO}_{2}$ production (VCO2; F), heat production $(\mathbf{G})$, daily food intake $(\mathbf{H})$, respiratory exchange ratio (RER; I), and locomotor activity $(\mathbf{J})$, determined by metabolic cage study, of 3-month-old male WT and AE mice. $n=7$ (A and $\mathbf{B}) ; n=6(\mathbf{E}-\mathbf{J}) .{ }^{*} P<0.05,{ }^{*} P<0.01$, and ${ }^{*} * x<0.001$ versus WT.

were collected for two consecutive 12-hour dark and light cycles. AE mice showed significantly higher $\mathrm{O}_{2}$ consumption $(P=0.0037), \mathrm{CO}_{2}$ production $(P=0.0012)$, and heat production $(P=0.0020)$ than WT mice (Figure $1, \mathrm{E}-\mathrm{G})$. AE mice also consumed more food $(P=0.0033)$ (Figure $1 \mathrm{H})$. The respiratory exchange ratio (Figure 1I) and activity (Figure $1 \mathrm{~J}$ ) of AE mice were similar to those of WT mice. AE mice showed better glucose tolerance than WT mice by a GTT, although their insulin tolerance remained the same as that of WT mice (Supplemental Figure S1). The data indicated that heat production and metabolic rate are increased in $\mathrm{AE}$ mice.
The Heat Production Change Is Independent of Skin Barrier Disruption in AE Mice

The metabolic alteration may be caused by a progressive hair loss and skin barrier disruption phenotype in AE mice. The metabolic parameters were measured when mice were maintained in a thermoneutral condition at $30^{\circ} \mathrm{C}$. The $\mathrm{AE}$ mice again displayed higher $\mathrm{O}_{2}$ consumption $(P=0.0406)$, $\mathrm{CO}_{2}$ production $(P=0.0200)$, heat production $(P<0.0001)$, and food consumption $(P=0.0483)$ than WT mice (Figure 2, A-D). Interestingly, the respiratory exchange ratio of AE mice was significantly lower than that 

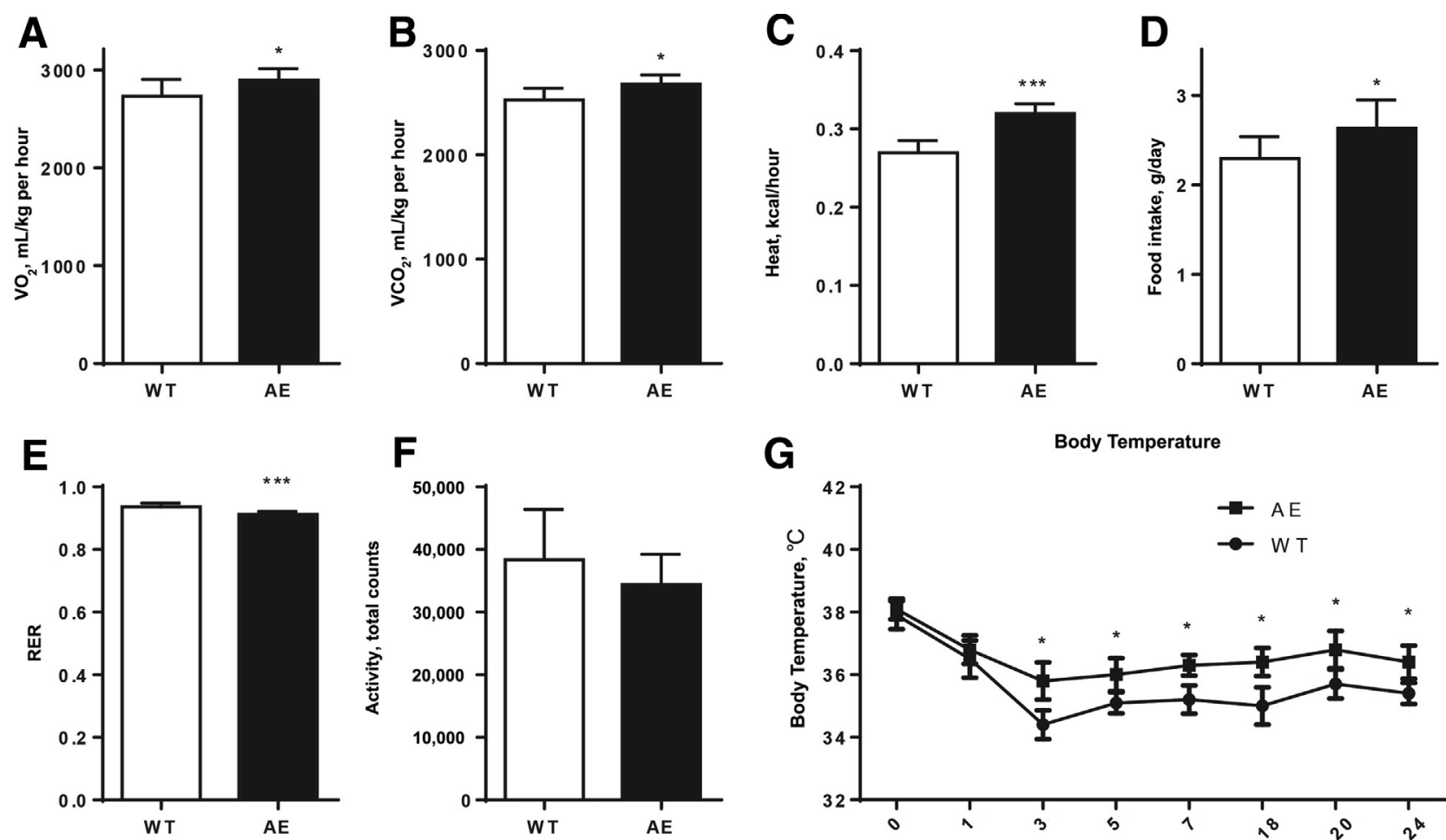

G

Body Temperature

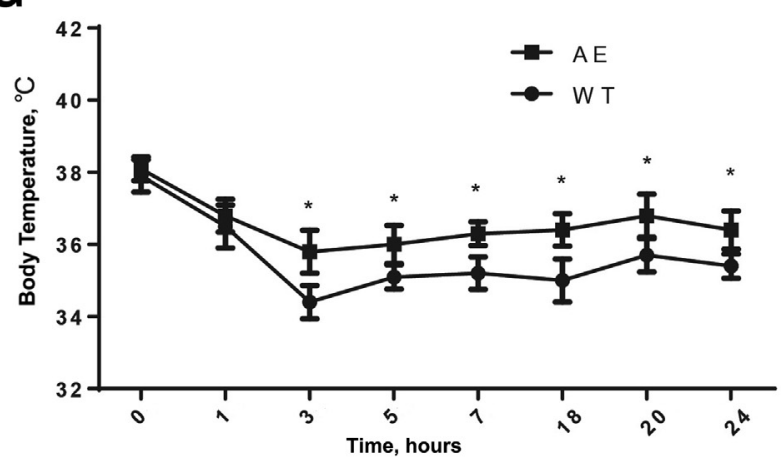

Figure 2 Increased heat production in AE mice is not related to skin barrier disruption. $\mathbf{A}-\mathrm{F}: \mathrm{O}_{2}(\mathbf{A}), \mathrm{CO}_{2}$ production (B), heat production (C), daily food intake (D), respiratory exchange ratio (RER; E), and locomotor activity (F), determined by metabolic cage study, of 3-month-old male WT and AE mice after 1 week of thermally neutralized treatment. G: Rectal temperature of 3 -month-old male mice after cold $\left(4^{\circ} \mathrm{C}\right)$ induction. $n=6(\mathbf{A}-\mathbf{F}) ; n=7(\mathbf{G}){ }^{*} P<0.05,{ }^{*} * *<0.001$ versus WT.

of WT mice, which suggests that AE mice like to use lipid as an energy resource $(P=0.0004)$ (Figure $2 \mathrm{E})$. The activity of AE mice showed no differences (Figure 2F). Furthermore, the AE mice could maintain body temperature better than WT mice at $4^{\circ} \mathrm{C}$ (Figure 2G). AE mice also showed better glucose tolerance than WT mice by a GTT, although their insulin tolerance remained the same as that of WT mice after 1 month of feeding in a thermoneutral condition $\left(30^{\circ} \mathrm{C}\right)$, just like in a room temperature condition (Supplemental Figure S2). All these data indicated that the increased heat production in $\mathrm{AE}$ mice was caused by upregulation of thermogenesis, which is not due to disruption of skin barrier function.

\section{Activation of BAT Thermogenesis in AE Mice}

BAT is crucial for cold-induced thermogenesis for maintaining body temperature. BAT is significantly smaller in AE mice, suggesting the activation of BAT. The lipid droplets were also found to be much smaller in the BAT of AE mice than that of WT mice, as seen by hematoxylin and eosin staining, which is consistent with the active status of thermogenesis in AE mice (Figure 3A). The expression of major thermogenic markers, ${ }^{24,25}$ including Ucpl ( $P=0.0017)$, peroxisome proliferator-activated receptor gamma coactivator 1-alpha PGC1A; (PPARGCIA; $P=0.0085)$, Cidea $(P=0.0060)$, Dio 2 $(P \leq 0.0001)$, and Tfam $(P=0.0159)$, was significantly up- regulated in the BAT of AE mice (Figure 3, B-F). However, the expression of the $\beta 3$-adrenergic receptor $(P=0.1258)$, which is a response to cold-induced thermogenesis through neural circuits, did not change significantly in the BAT of AE mice compared with that of WT mice. This result is consistent with our metabolic cage data. The markers of lipid oxidation and lipolysis ${ }^{26,27}$ were also significantly up-regulated in the BAT of AE mice (Supplemental Figure S3A). The thermogenic markers were also tested in s.c. fat, and there was no upregulation of those markers; some markers were even downregulated in AE mice, suggesting that there is no white adipose tissue (WAT) browning (Supplemental Figure S3B). Although skeletal muscle is another important organ for heat production, there were no significant changes in the muscles of WT and AE mice (Supplemental Figure S3C). The data above suggested that BAT activation played a key role in the upregulation of thermogenesis in $\mathrm{AE}$ mice.

IL-6 Is the Key Candidate for Inducing Up-Regulation of Heat Production after Gsdma3 Activation in the Epidermis

The activation of heat production cannot be an in situ effect because Gsdma3 is exclusively expressed in skin tissues. ${ }^{15,28,29}$ Therefore, it is reasonable to assume that some specific factor(s) released from skin induce the activation of BAT and thermogenesis. Indeed, expression of Dio2 was 
A

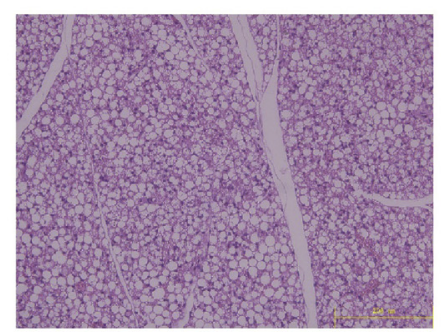

D

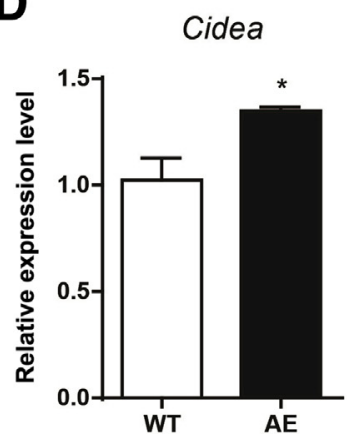

AE

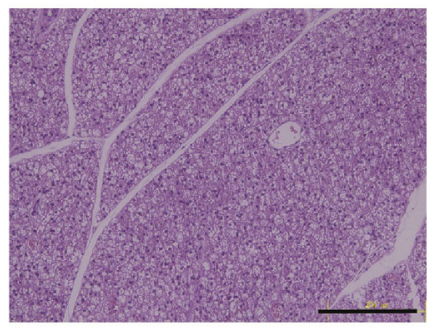

$\mathbf{E}$

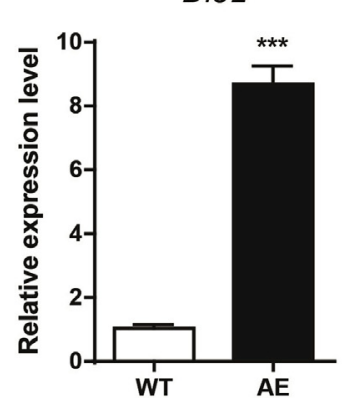

B

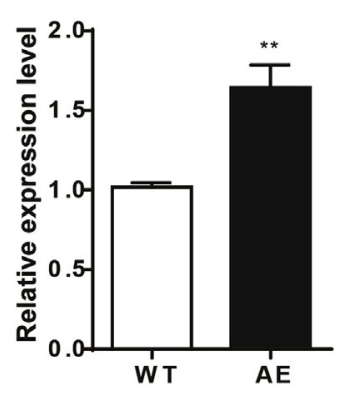

$\mathbf{F}$

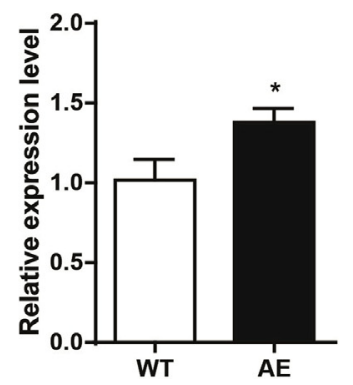

Pgc1a

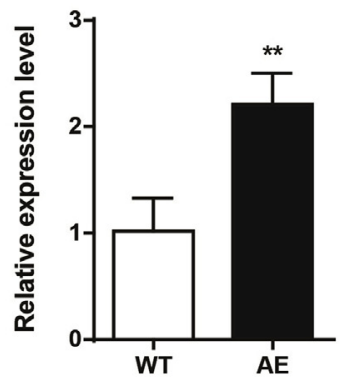

G ß3-adrenergic receptor

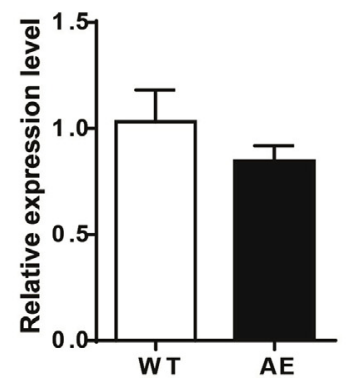

Figure 3 Increased heat production in AE mice is due to the up-regulation of brown adipose tissue (BAT) thermogenesis. A: Representative histology of BAT in WT and AE mice. B-G: UCP1 (B), PGC1A (PPARGC1A; C), Cidea (D), DI02 (E), Tfam (F), and 33 receptor (G) mRNA levels in BAT from 3-month-old male mice, measured by real-time quantitative PCR. Expression levels of target genes were normalized to RplpO (alias 36B4), and data were calculated using the $2^{-\Delta \Delta \mathrm{Ct}}$ method. $n=6(\mathbf{A}-\mathbf{G}) .{ }^{*} P<0.05,{ }^{*} P<0.01$, and ${ }^{* *} * P<0.001$ versus WT. Scale bar $=200 \mu \mathrm{m}(\mathbf{A})$. PPARGC1A, peroxisome proliferator-activated receptor gamma coactivator 1 -alpha.

significantly up-regulated when primary BAT cells from newborn WT mice were treated with serum from AE mice for 4 hours $(P=0.0179)$ (Figure 4A). Expression of $U c p 1$ $(P=0.1839)$, PGC1A (PPARGC1A; $P=0.2357)$, and Cidea $(P=0.2207)$ was also increased but not significantly (Figure 4, B-D). Consistently, Dio2 expression was also strongly up-regulated in the BAT of AE mice (Figure 3E), indicating its crucial role in heat production of $\mathrm{AE}$ mice.

The factors released in the serum of AE mice were identified by expressing the Gsdma3 $\mathrm{N}$ terminus, which was mimicked by expression of the Gadma3 mutant form in $\mathrm{HaCaT}$ cells. A tet-on lentivirus system was used to generate doxycycline (DOX)-induced Gsdma3 N-terminus and C-terminus stably transfected $\mathrm{HaCaT}$ cell lines. These cell lines were induced for 10 hours by DOX. The expression of major cytokines (IL-1 $\beta$, IL-2, IL-4, IL-6, IL-8, IL-10, IL-12, IL-17 $\alpha$, IL-18, interferon$\alpha$, interferon- $\gamma$, and tumor necrosis factor- $\alpha$ ) was then examined. The expression of the $\mathrm{N}$ terminus caused a significant upregulation of IL6 by quantitative RT-PCR $(P<0.0001)$ (Figure 4E). IL6 was up-regulated after 8 hours of DOXinduced expression of the $\mathrm{N}$ terminus by quantitative RTPCR $(P<0.0001)$ (Figure 4F). The IL-6 level in the supernatant of $\mathrm{HaCaT}$ cells was significantly up-regulated after Gsdma3 N-terminus expression $(P=0.0027)$ (Figure $4 \mathrm{G})$. The expression level of major cytokines was also determined in skin of AE mice. Consistent with Gsdma3 N-terminus transfected $\mathrm{HaCaT}$ cells, IL6 was extremely significantly upregulated in the skin of $\mathrm{AE}$ mice; other cytokines demonstrated slightly elevated or no significant change (Supplemental Figure S4).

IL-6 was the first identified myokine, which was secreted by muscle after exercise and promoted lipid oxidation. ${ }^{30}$ Mice overexpressing IL-6 displayed improved metabolic phenotypes. ${ }^{31-33}$ The IL-6 level was significantly higher in the serum of AE mice than in the serum of WT mice $(P=0.0007)$ (Figure 4H). The expression level of IL-6 was also up-regulated in the skin of AE mice $(P \leq 0.0001)$ (Figure $4 \mathrm{I})$. Downstream of IL-6 is the Stat 3 signaling pathway. The phosphorylation level of Stat 3 was examined in the BAT because Stat 3 is the direct downstream target after activation of the IL- 6 receptor. The phosphorylation level of Stat3 was significantly up-regulated in the BAT of AE mice (Figure $4 \mathrm{~J}$ ). All these results indicated that IL-6 is the key candidate for inducing up-regulation of heat production after Gsdma3 activation in the epidermis.

\section{Blockage of IL-6 Signaling Suppresses the Up-Regulation of Heat Production in AE Mice}

Speculating that IL-6 might mediate BAT activation in AE mice, SC-144, an inhibitor, was used to block the function of GP130, which is the main subunit of the IL-6 receptor. ${ }^{34}$ SC-144 has been reported to block IL-6-induced Stat3 activation. ${ }^{35}$ After i.p. injection of SC-144 for 2 days, the phosphorylation level of Stat3 in BAT was significantly down-regulated in SC-144-treated mice compared with control mice (Figure 5A). Furthermore, the expression of 

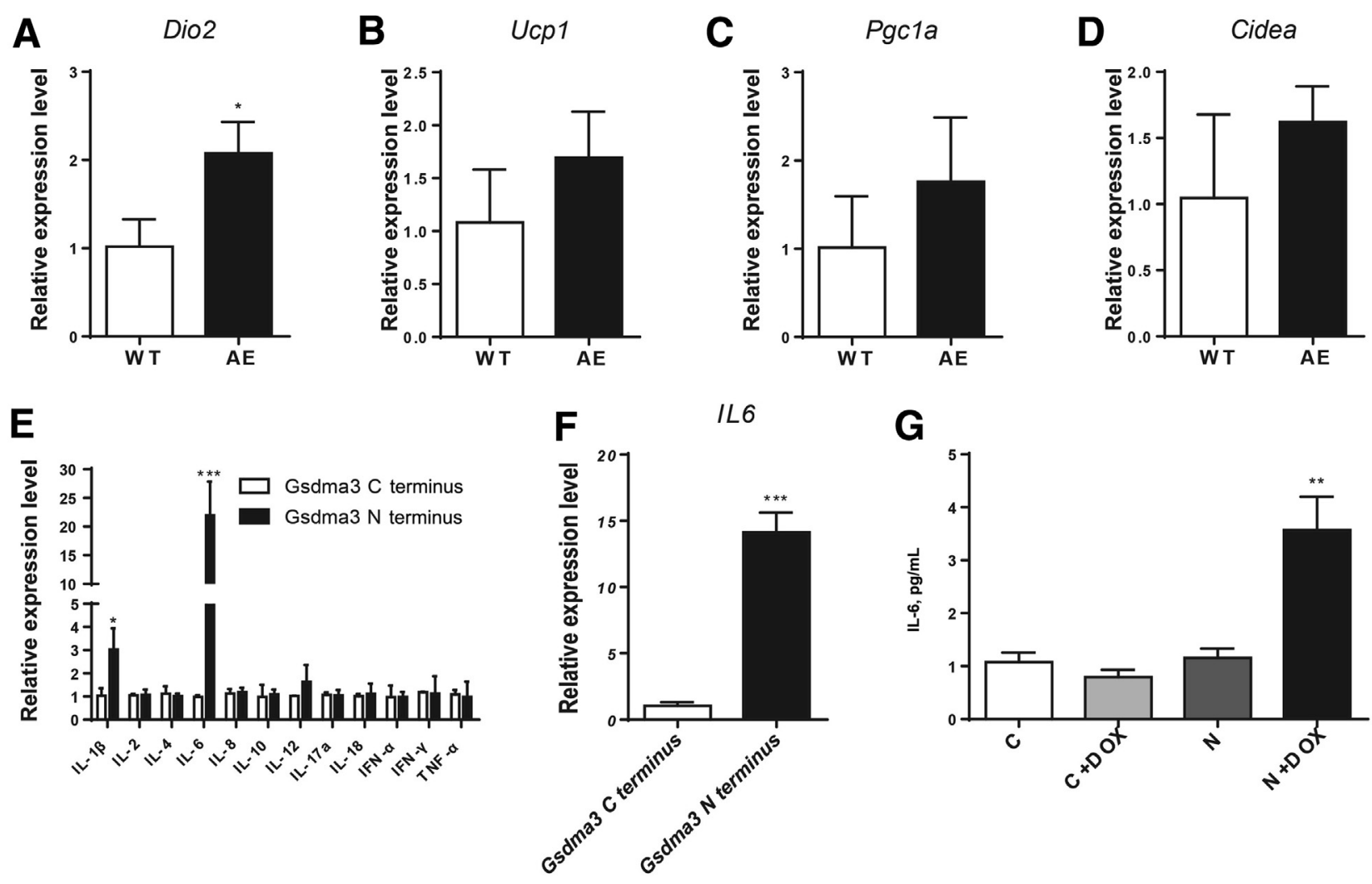

G
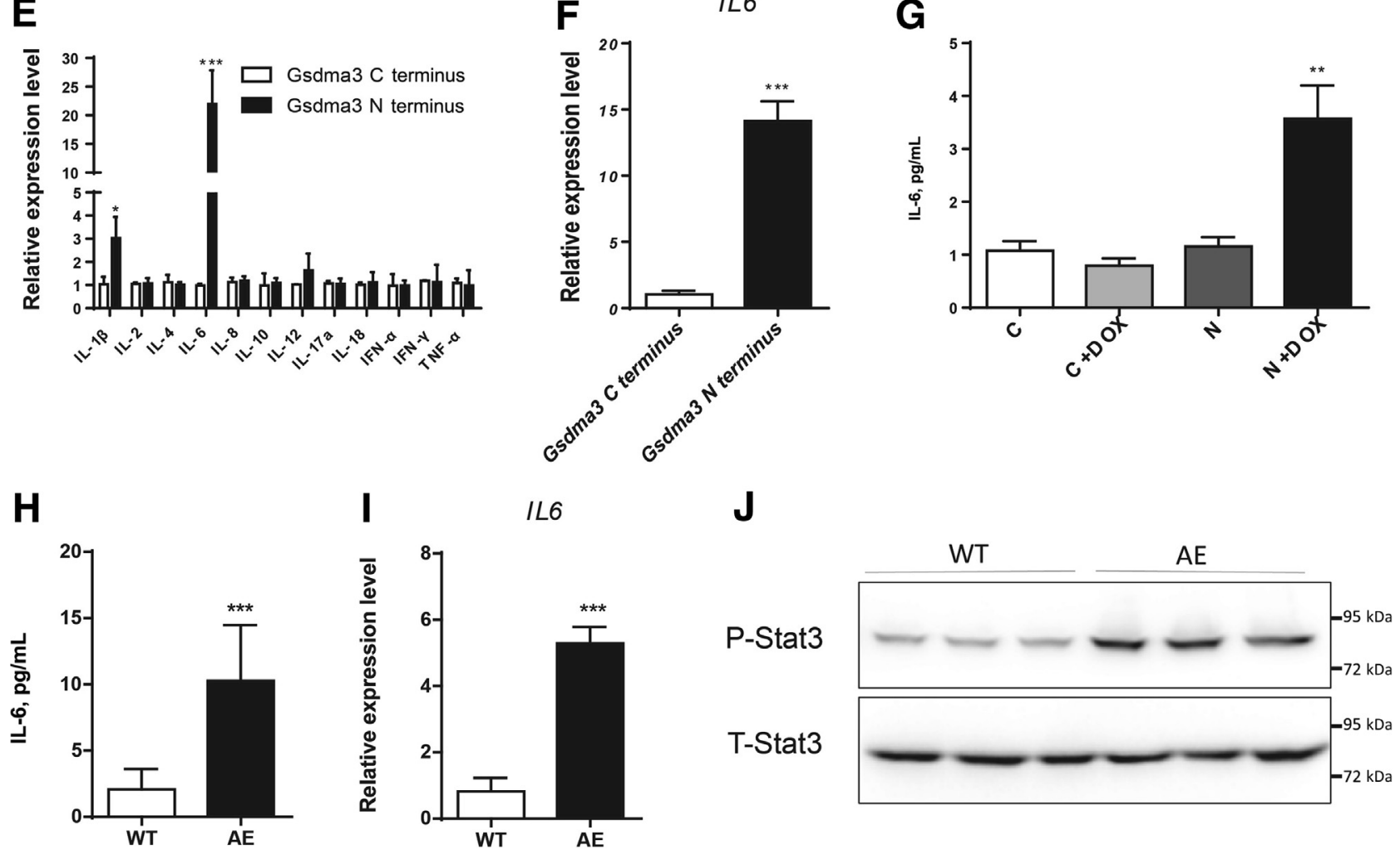

Figure 4 IL-6 is significantly up-regulated after Gsdma3 activation. A-D: DIO2 (A), UCP1 (B), PGC1A (PPARGC1A; C), and Cidea (D) mRNA levels, measured by real-time quantitative PCR ( $\mathrm{PPCR}$ ), in primary brown adipose tissue (BAT) cells after 4 hours of WT and AE serum treatment. E: mRNA levels of several cytokines in HaCaT cells, measured by qPCR, after 10 hours of DOX-induced Gsdma3 N-terminus and C-terminus expression. F: The mRNA levels of IL6 in HaCaT cells after 8 hours of doxycycline (DOX)-induced Gsdma3 N-terminus and C-terminus expression. G: IL-6 levels in supernatant after 10 hours of D0X-induced Gsdma3 $\mathrm{N}$-terminus (N) and C-terminus (C) expression and control measured by enzyme-linked immunosorbent assay (ELISA). H: IL-6 levels in WT and AE serum, measured by ELISA. I: The mRNA levels of IL6 in skin from WT and AE mice, measured by qPCR. J: The phosphorylation and expression levels of Stat3 in BAT from WT and AE mice. The estimated amount of target cDNA was normalized to Rplpo (alias 36B4) in each sample before comparison. $n=6$ (A-F, $\mathbf{H}$, and I) $; n=3(\mathbf{G}) .{ }^{*} P<0.05,{ }^{*} P<0.01$, and ${ }^{* * *} P<0.001$ versus WT. IFN, interferon; P-Stat3, phosphorylated stat3; TNF- $\alpha$, tumor necrosis factor- $\alpha$; T-Stat3, total stat3. PPARGC1A, peroxisome proliferator-activated receptor gamma coactivator 1-alpha.

major thermogenic markers, including UCP1, PGC1A (PPARGC1A), Cidea, Dio2, and Tfam, was significantly down-regulated in BAT of SC-144-treated mice (Supplemental Figure S5). After 2 weeks of SC-144 treatment, $\mathrm{AE}$ mice showed a significant down-regulation of heat production $(P=0.0115)$ by metabolic cage measurement (Figure 5B). The $\mathrm{O}_{2}$ consumption $(P=0.0852)$ and $\mathrm{CO}_{2}$ production $(P=0.1864)$ also showed slight decreases compared with control mice but were not significantly different (Figure 5, C and D). The food intake, respiratory exchange ratio, and activity showed no significant changes (Supplemental Figure S6). After 2 days of SC-144 i.p. injection, the GTT and insulin tolerance test showed no differences between WT and AE mice (Figure 5, E and F). To further confirm that IL-6 is an important mediator between skin and brown adipose tissue, IL-6-neutralizing monoclonal antibody was used to directly block IL-6 in vivo. Consistent with SC-144-treated AE mice, the heat production, volume of $\mathrm{O}_{2}$ consumption, and volume of $\mathrm{CO}_{2}$ production were also significantly down-regulated in IL-6 


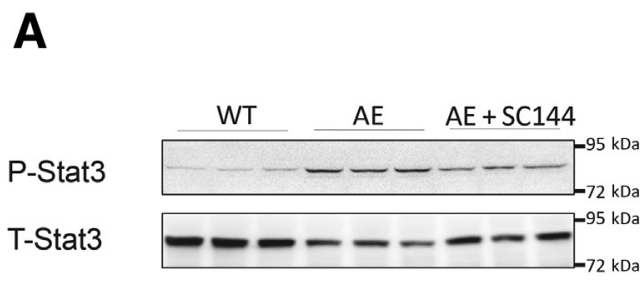

D

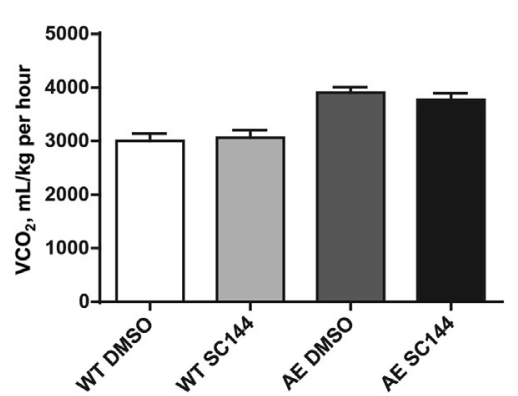

B

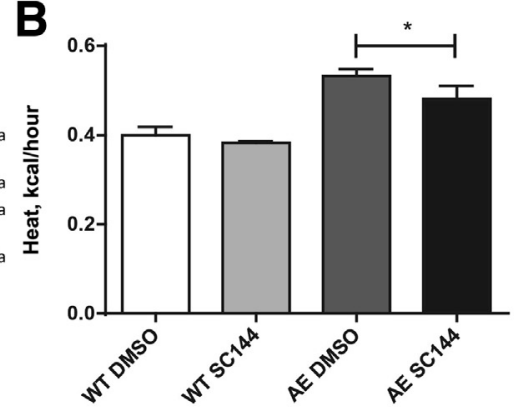

E

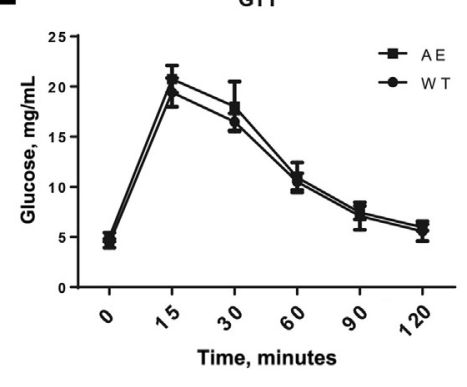

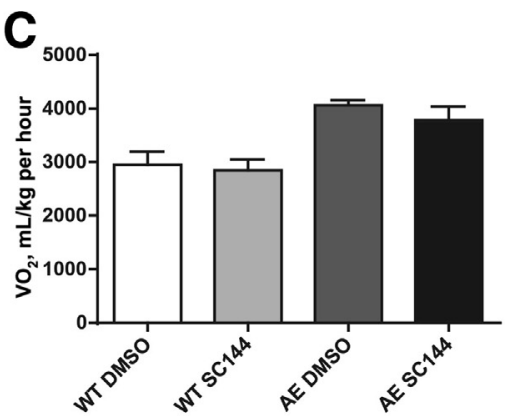

$\mathbf{F}$

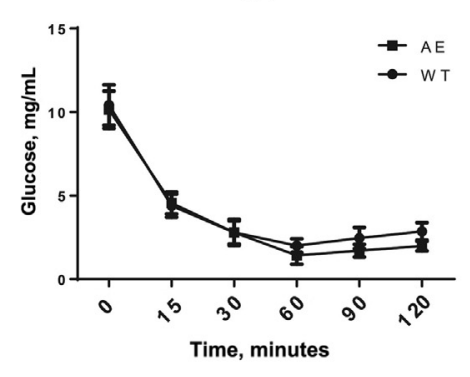

Figure 5 Blockage of IL-6 signaling may suppress the up-regulation of heat production in AE mice. A: The phosphorylation and expression levels of Stat3 in brown adipose tissue from WT mice injected with dimethyl sulfoxide (DMSO) and AE mice injected with DMSO and SC144, at 2 days. B-D: Heat (B), $0_{2}$ (C), and $\mathrm{CO}_{2}$ (D) production, determined by metabolic cage study, of 3-month-old male WT and AE mice after 2 weeks of SC144 i.p. injection. E: Glucose tolerance test (GTT) of 3-month-old male WT and AE mice after 2 days of SC144 i.p. injection. F: Insulin tolerance test (ITT) of 3-month-old male WT and AE mice after 2 days of SC144 i.p. injection. $n=6(\mathbf{B}-\mathbf{F}) .{ }^{*} P<0.05$. P-Stat3, phosphorylated stat3; T-Stat3, total stat3.

antibody - treated AE mice (Supplemental Figure S7). These data indicated that IL-6/Stat3 signaling mediated the upregulation of thermogenesis in $\mathrm{AE}$ mice.

\section{Gsdma3 Activation Induces IL-6 Expression through the JNK Signaling Pathway}

There have been several reports suggesting that mitogenactivated protein kinase signaling is involved in regulating IL6 gene expression. ${ }^{36-38}$ The phosphorylation of JNK and extracellular signal-regulated kinase was significantly upregulated after Gsdma3 N-terminus expression in $\mathrm{HaCaT}$ cell lines (Figure 6A), indicating that Gsdma3 activation might activate mitogen-activated protein kinase and then upregulate IL-6 expression. Furthermore, the expression of IL6 was significantly suppressed by JNK-specific inhibitor SP600125 in a dose-dependent manner $(P<0.0001)$ (Figure 6B), whereas the extracellular signal-regulated kinase-specific inhibitor U1026 did not affect IL6 expression (Figure $6 \mathrm{C}$ ). These results demonstrated that IL-6 is induced by JNK.

JNK and extracellular signal-regulated kinase activation was examined in the skin of AE mice. The phosphorylation level of JNK was significantly up-regulated in the skin of AE mice compared with that of WT mice (Figure 6D). Immunostaining also showed that phosphorylated JNK and phosphorylated c-Jun, downstream of JNK, were significantly up-regulated in the epidermis of AE mice (Figure 6E and Supplemental Figure S8). Taken together, these data indicated that the JNK-IL-6 pathway was activated in vivo after Gsdma3 activation.

\section{Discussion}

Our results showed that a Gsdma3 active mutation significantly increased whole-body and BAT heat production through skin-originated IL-6 function. These data suggested a novel mechanism for skin regulation of whole-body metabolism through the humoral system. Gsdma3 activation was found to cause up-regulation of IL-6 expression through the JNK signaling pathway. This function is different from the activation of pyroptosis by Gsdmd, another GSDM family member. ${ }^{18,19}$

Because members of the GSDM family localize at the barrier, such as the epidermis, intestine, and colon, and GSDMD plays an important role in innate immunity, ${ }^{19}$ other GSDM members might also be involved in immunity. The inflammasome pathway, in which GSDMD is the final executor, mainly defends against intracellular bacterial infection. The body barrier is the forefront of the microbial invasion. Thus, other members of the GSDM family might be involved in microbial resistance. In the future, we expect more discoveries using a variety of microbial infection models to fully understand the physiological function of Gsdma3/GSDMA.

Similar to AE mice, several mouse strains with skin defects have been reported to associate with metabolic phenotypes. ${ }^{1}$ For instance, Scdl skin-specific knockout mice also display increased heat production. ${ }^{2,3}$ However, the 

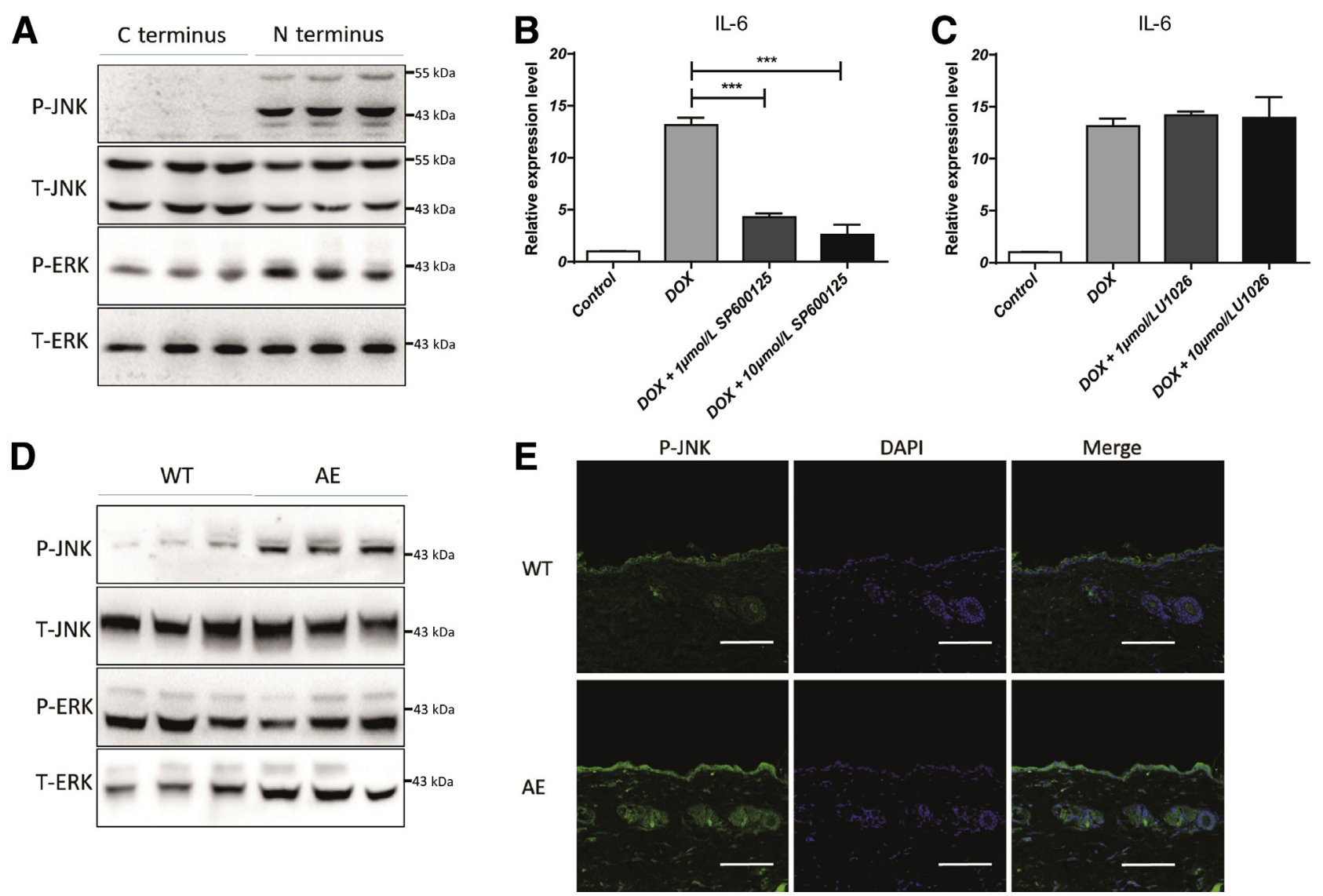

Figure 6 Gsdma3 activation may activate c-Jun N-terminal kinase (JNK) signaling and induce IL-6 expression. A: The phosphorylation and expression levels of JNK and extracellular signal-regulated kinase (ERK) in HaCaT cells after 10 hours of DOX-induced Gsdma3 N-terminus and C-terminus expression. B: The mRNA levels of IL-6 after JNK inhibitor SP00125 treatment. C: The mRNA levels of IL-6 after ERK inhibitor U1026 treatment. D: The phosphorylation and expression levels of JNK and ERK in the skin of 3-month-old male WT and AE mice. E: The immunostaining of phosphorylated JNK in skin of WT and AE mice. $n=6(\mathbf{B}$ and $\mathbf{C}) .{ }^{* *} P<0.001$. Scale bar $=50 \mu \mathrm{m}(\mathrm{E}) . \mathrm{P}$, phosphorylated; $\mathrm{T}$, total.

Scdl-SKO mice are different from Gsdma3-mutant mice in the physiological mechanism for metabolic phenotypes. In Scd1-SKO mice, $\beta 3$-adrenergic receptor signaling in BAT, a marker of cold exposure, was elevated when the mice were housed at room temperature, suggesting increased cold perception in these mice even at room temperature. ${ }^{39,40}$ However, there is no difference in $\beta 3$-adrenergic receptor expression levels between WT and AE mice (Figure $3 \mathrm{G}$ ). The AE mice could maintain body temperature better than WT mice in the $4^{\circ} \mathrm{C}$ condition. The heat production of $\mathrm{AE}$ mice was also increased at a thermoneutral temperature, which further ruled out the cold-sensing activation through thermoreceptors and the nervous system in $\mathrm{AE}$ mice. ${ }^{4}$ The mutant form of Gsdma3 in AE mice represents the activation of Gsdma3 because the point mutation in the $\mathrm{C}$-terminal domain releases the inhibitory function of the C-terminal domain to the functional N-terminal domain. ${ }^{20}$ In Gsdmd, this activation is achieved by the cleavage of a hinge region between the $\mathrm{N}$-terminal domain and the $\mathrm{C}$-terminal domain by caspase- 1 and caspase- $4 / 5 / 11{ }^{19,41,42}$ There still remains the unsolved question of what endogenously triggers the initial activation of Gsdma3 in skin. Although most studies on GSDM family genes involve the process of inflammation, this study found, for the first time, that one of the functions of active Gsdma3 is to induce the expression of IL-6 and eventually increase whole-body heat production.

The function of IL-6 in regulating heat production has been proposed in many studies. First identified as a myokine, IL-6 is secreted from muscles after exercise. ${ }^{30,43}$ IL-6 can act on liver and fat to increase lipid oxidation and glucose uptake, which up-regulates the metabolic rate. ${ }^{30,43,44}$ Mice overexpressing IL-6 displayed an improved metabolic rate and reserved body weight gain. ${ }^{32,33}$ In contrast, IL-6 knockout mice showed adult obesity and leptin resistance. ${ }^{45-47}$ Stat3, downstream of IL-6, also played an important role in BATdependent thermogenesis. Disruption of Stat3 expression can prevent functional development of brown adipocytes. ${ }^{48}$ The elevated IL-6 level in serum and related activation of BAT in AE mice are consistent with previous studies, ${ }^{30-32}$ which note a novel functional cross talk between skin and other major organs for metabolic regulation.

Previous studies showed highly elevated catecholamine-, corticosteroid-, and inflammatory cytokine-mediated hypermetabolic responses. ${ }^{13,49}$ IL-6 was one of the up-regulated cytokines after burn injury, ${ }^{50}$ and positively correlated to body temperature increase. ${ }^{51}$ Thus, burn- 
injury-induced increase of heat production in BAT may suggest that the keratinocytes secreted IL-6. The burn injury or other stimulation might activate JNK/c-Jun signaling in keratinocytes and induce IL-6 secretion as another signaling mechanism to regulate metabolism. ${ }^{52,53}$ These results are consistent with our finding, suggesting IL-6 is an important regulator between skin and BAT after burning injury.

In conclusion, our results uncovered Gsdma3/IL-6/Stat3dependent cross talk between the skin and BAT. The novel mechanism for skin regulation of whole-body metabolism also provides a new way to treat other metabolic syndromes.

\section{Acknowledgments}

We thank Prof. Di Chen (Nanjing University, Nanjing, China) for valuable suggestions.

P.S. and Q.C. conducted most of the experiments, analyzed data, and prepared figures; Y.W., D.Z., D.W., and Z.H. constructed plasmids; Q.C., P.S., Z.L., and X.G. designed experiments and wrote the manuscript; X.G. and Z.L. designed the study and edited and revised the manuscript; all authors reviewed the results and approved the final version of the manuscript.

\section{Supplemental Data}

Supplemental material for this article can be found at https://doi.org/10.1016/j.ajpath.2019.01.012.

\section{References}

1. Kruse V, Neess D, Faergeman NJ: The significance of epidermal lipid metabolism in whole-body physiology. Trends Endocrinol Metab 2017, 28:669-683

2. Sampath H, Ntambi JM: Role of stearoyl-CoA desaturase-1 in skin integrity and whole body energy balance. J Biol Chem 2014, 289: $2482-2488$

3. Sampath H, Flowers MT, Liu X, Paton CM, Sullivan R, Chu K, Zhao M, Ntambi JM: Skin-specific deletion of stearoyl-CoA desaturase-1 alters skin lipid composition and protects mice from high fat diet-induced obesity. J Biol Chem 2009, 284:19961-19973

4. Nakamura K: Central circuitries for body temperature regulation and fever. Am J Physiol Regul Integr Comp Physiol 2011, 301: R1207-R1228

5. Morrison SF: Central neural control of thermoregulation and brown adipose tissue. Auton Neurosci 2016, 196:14-24

6. Wolk K, Sabat R: Adipokines in psoriasis: an important link between skin inflammation and metabolic alterations. Rev Endocr Metab Disord 2016, 17:305-317

7. Sommer DM, Jenisch S, Suchan M, Christophers E, Weichenthal M: Increased prevalence of the metabolic syndrome in patients with moderate to severe psoriasis. Arch Dermatol Res 2006, 298:321-328

8. Azfar RS, Gelfand JM: Psoriasis and metabolic disease: epidemiology and pathophysiology. Curr Opin Rheumatol 2008, 20:416-422

9. Kim EJ, Kim YK, Kim JE, Kim S, Kim MK, Park CH, Chung JH: UV modulation of subcutaneous fat metabolism. J Invest Dermatol 2011, 131:1720-1726

10. Yo K, Yu YM, Zhao G, Bonab AA, Aikawa N, Tompkins RG, Fischman AJ: Brown adipose tissue and its modulation by a mitochondria-targeted peptide in rat burn injury-induced hypermetabolism. Am J Physiol Endocrinol Metab 2013, 304:E331-E341

11. Carter EA, Winter D, Tolman C, Paul K, Hamrahi V, Tompkins RG, Fischman AJ: Combination of radiation and burn injury alters [(1)(8) F] 2-fluoro-2-deoxy-D-glucose uptake in mice. J Burn Care Res 2012, 33:723-730

12. Gore DC, Chinkes D, Sanford A, Hart DW, Wolf SE, Herndon DN: Influence of fever on the hypermetabolic response in burn-injured children. Arch Surg 2003, 138:169-174; discussion 174

13. Williams FN, Herndon DN: Metabolic and endocrine considerations after burn injury. Clin Plast Surg 2017, 44:541-553

14. Herndon DN, Tompkins RG: Support of the metabolic response to burn injury. Lancet 2004, 363:1895-1902

15. Tamura M, Tanaka S, Fujii T, Aoki A, Komiyama H, Ezawa K, Sumiyama K, Sagai T, Shiroishi T: Members of a novel gene family, Gsdm, are expressed exclusively in the epithelium of the skin and gastrointestinal tract in a highly tissue-specific manner. Genomics 2007, 89:618-629

16. Aglietti RA, Estevez A, Gupta A, Ramirez MG, Liu PS, Kayagaki N, Ciferri C, Dixit VM, Dueber EC: GsdmD p30 elicited by caspase-11 during pyroptosis forms pores in membranes. Proc Natl Acad Sci U S A 2016, 113:7858-7863

17. Sborgi L, Ruhl S, Mulvihill E, Pipercevic J, Heilig R, Stahlberg H, Farady CJ, Muller DJ, Broz P, Hiller S: GSDMD membrane pore formation constitutes the mechanism of pyroptotic cell death. EMBO J 2016, 35:1766-1778

18. Gaidt MM, Hornung V: Pore formation by GSDMD is the effector mechanism of pyroptosis. EMBO J 2016, 35:2167-2169

19. Shi J, Zhao Y, Wang K, Shi X, Wang Y, Huang H, Zhuang Y, Cai T, Wang F, Shao F: Cleavage of GSDMD by inflammatory caspases determines pyroptotic cell death. Nature 2015, 526:660-665

20. Shi P, Tang A, Xian L, Hou S, Zou D, Lv Y, Huang Z, Wang Q, Song A, Lin Z, Gao X: Loss of conserved Gsdma3 self-regulation causes autophagy and cell death. Biochem J 2015, 468:325-336

21. Zhou Y, Jiang X, Gu P, Chen W, Zeng X, Gao X: Gsdma3 mutation causes bulge stem cell depletion and alopecia mediated by skin inflammation. Am J Pathol 2012, 180:763-774

22. Huang Z, Ruan HB, Xian L, Chen W, Jiang S, Song A, Wang Q, Shi $\mathrm{P}, \mathrm{Gu} \mathrm{X}$, Gao X: The stem cell factor/Kit signalling pathway regulates mitochondrial function and energy expenditure. Nat Commun 2014, 5:4282

23. Barkhausen $T$, Tschernig $T$, Rosenstiel $P$, Van Griensven $M$, Vonberg R, Dorsch M, Muellerheine A, Chalaris A, Scheller J, Rosejohn S: Selective blockade of interleukin-6 trans-signaling improves survival in a murine polymicrobial sepsis model. Crit Care Med 2011, 39:1407-1413

24. De Pauw A, Tejerina S, Raes M, Keijer J, Arnould T: Mitochondrial (dys)function in adipocyte (de)differentiation and systemic metabolic alterations. Am J Pathol 2009, 175:927-939

25. Lau P, Tuong ZK, Wang S, Fitzsimmons RL, Goode JM, Thomas GP, Cowin G, Pearen MA, Mardon K, Stow JL: Ror $\alpha$ deficiency and decreased adiposity are associated with induction of thermogenic gene expression in subcutaneous white adipose and brown adipose tissue. Am J Physiol Endocrinol Metab 2015, 308:E159-E171

26. Kim KH, Jeong YT, Oh H, Kim SH, Cho JM, Kim Y, Kim SS, Kim DH, Hur KY, Kim HK: Autophagy deficiency leads to protection from obesity and insulin resistance by inducing Fgf21 as a mitokine. Nat Med 2013, 19:83-92

27. Asterholm IW, Scherer PE: Enhanced metabolic flexibility associated with elevated adiponectin levels. Am J Pathol 2010, 176: $1364-1376$

28. Tanaka S, Mizushina Y, Kato Y, Tamura M, Shiroishi T: Functional conservation of Gsdma cluster genes specifically duplicated in the mouse genome: G3: genes, genomes. Genetics 2013, 3:1843-1850

29. Tanaka S, Tamura M, Aoki A, Fujii T, Komiyama H, Sagai T, Shiroishi T: A new Gsdma3 mutation affecting anagen phase of first hair cycle. Biochem Biophys Res Commun 2007, 359:902-907 
30. Pal M, Febbraio MA, Whitham M: From cytokine to myokine: the emerging role of interleukin-6 in metabolic regulation. Immunol Cell Biol 2014, 92:331-339

31. Stanford KI, Middelbeek RJ, Townsend KL, An D, Nygaard EB, Hitchcox KM, Markan KR, Nakano K, Hirshman MF, Tseng YH, Goodyear LJ: Brown adipose tissue regulates glucose homeostasis and insulin sensitivity. J Clin Invest 2013, 123:215-223

32. Sadagurski M, Norquay L, Farhang J, D’Aquino K, Copps K, White MF: Human IL6 enhances leptin action in mice. Diabetologia 2010, 53:525-535

33. Ma Y, Gao M, Sun H, Liu D: Interleukin-6 gene transfer reverses body weight gain and fatty liver in obese mice. Biochim Biophys Acta 2015, 1852:1001-1011

34. Heinrich PC, Behrmann I, Haan S, Hermanns HM, Muller-Newen G, Schaper F: Principles of interleukin (IL)-6-type cytokine signalling and its regulation. Biochem J 2003, 374:1-20

35. Xu S, Grande F, Garofalo A, Neamati N: Discovery of a novel orally active small-molecule gp130 inhibitor for the treatment of ovarian cancer. Mol Cancer Ther 2013, 12:937-949

36. Sano M, Fukuda K, Sato T, Kawaguchi H, Suematsu M, Matsuda S, Koyasu S, Matsui H, Yamauchi-Takihara K, Harada M, Saito Y, Ogawa S: ERK and p38 MAPK, but not NF-kappaB, are critically involved in reactive oxygen species-mediated induction of IL-6 by angiotensin II in cardiac fibroblasts. Circ Res 2001, 89:661-669

37. Tuyt LM, Dokter WH, Birkenkamp K, Koopmans SB, Lummen C, Kruijer W, Vellenga E: Extracellular-regulated kinase 1/2, Jun $\mathrm{N}$-terminal kinase, and c-Jun are involved in NF-kappa B-dependent IL-6 expression in human monocytes. J Immunol 1999, 162: 4893-4902

38. Jang S, Kelley KW, Johnson RW: Luteolin reduces IL-6 production in microglia by inhibiting JNK phosphorylation and activation of AP1. Proc Natl Acad Sci U S A 2008, 105:7534-7539

39. Guerra C, Koza RA, Yamashita H, Walsh K, Kozak LP: Emergence of brown adipocytes in white fat in mice is under genetic control: effects on body weight and adiposity. J Clin Invest 1998, 102:412-420

40. Himms-Hagen J, Melnyk A, Zingaretti MC, Ceresi E, Barbatelli G, Cinti S: Multilocular fat cells in WAT of CL-316243-treated rats derive directly from white adipocytes. Am J Physiol Cell Physiol 2000, 279:C670-C681

41. Kayagaki N, Stowe IB, Lee BL, O'Rourke K, Anderson K, Warming S, Cuellar T, Haley B, Roose-Girma M, Phung QT, Liu PS, Lill JR, Li H, Wu J, Kummerfeld S, Zhang J, Lee WP, Snipas SJ, Salvesen GS, Morris LX, Fitzgerald L, Zhang Y, Bertram EM,
Goodnow CC, Dixit VM: Caspase-11 cleaves gasdermin D for noncanonical inflammasome signalling. Nature 2015, 526:666-671

42. He WT, Wan $\mathrm{H}$, Hu L, Chen P, Wang X, Huang Z, Yang ZH, Zhong CQ, Han J: Gasdermin D is an executor of pyroptosis and required for interleukin-1beta secretion. Cell Res 2015, 25:1285-1298

43. Pedersen BK, Febbraio MA: Muscle as an endocrine organ: focus on muscle-derived interleukin-6. Physiol Rev 2008, 88:1379-1406

44. Pedersen BK, Fischer CP: Beneficial health effects of exercise: the role of IL-6 as a myokine. Trends Pharmacol Sci 2007, 28:152-156

45. Wallenius V, Wallenius K, Ahren B, Rudling M, Carlsten $\mathrm{H}$, Dickson SL, Ohlsson C, Jansson JO: Interleukin-6-deficient mice develop mature-onset obesity. Nat Med 2002, 8:75-79

46. Matthews VB, Allen TL, Risis S, Chan MH, Henstridge DC, Watson N, Zaffino LA, Babb JR, Boon J, Meikle PJ, Jowett JB, Watt MJ, Jansson JO, Bruce CR, Febbraio MA: Interleukin-6-deficient mice develop hepatic inflammation and systemic insulin resistance. Diabetologia 2010, 53:2431-2441

47. Mukumoto H, Takahashi Y, Ando M, Nishikawa M, Takakura Y: Expression profile-dependent improvement of insulin sensitivity by gene delivery of interleukin-6 in a mouse model of type II diabetes. Mol Pharm 2013, 10:3812-3821

48. Derecka M, Gornicka A, Koralov SB, Szczepanek K, Morgan M, Raje V, Sisler J, Zhang Q, Otero D, Cichy J, Rajewsky K, Shimoda K, Poli V, Strobl B, Pellegrini S, Harris TE, Seale P, Russell AP, McAinch AJ, O'Brien PE, Keller SR, Croniger CM, Kordula T, Larner AC: Tyk2 and Stat 3 regulate brown adipose tissue differentiation and obesity. Cell Metab 2012, 16:814-824

49. Williams FN, Jeschke MG, Chinkes DL, Suman OE, Branski LK Herndon DN: Modulation of the hypermetabolic response to trauma: temperature, nutrition, and drugs. J Am Coll Surg 2009, 208:489-502

50. Hur J, Yang HT, Chun W, Kim JH, Shin SH, Kang HJ, Kim HS: Inflammatory cytokines and their prognostic ability in cases of major burn injury. Ann Lab Med 2015, 35:105-110

51. Caldwell FT Jr, Graves DB, Wallace BH: Pathogenesis of fever in a rat burn model: the role of cytokines and lipopolysaccharide. J Burn Care Rehabil 1997, 18:525-530

52. Assefa Z, Garmyn M, Bouillon R, Merlevede W, Vandenheede JR, Agostinis P: Differential stimulation of ERK and JNK activities by ultraviolet B irradiation and epidermal growth factor in human keratinocytes. J Invest Dermatol 1997, 108:886-891

53. Zhai Y, Dang Y, Gao W, Zhang Y, Xu P, Gu J, Ye X: P38 and JNK signal pathways are involved in the regulation of phlorizin against UVB-induced skin damage. Exp Dermatol 2015, 24:275-279 